$\begin{array}{lcl}\text { Bentham OPEN } & \text { Open Medicine Journal } \\ \text { CrossMark } & \text { Content list available at: www.benthamopen.com/MEDJ/ } \\ \text { DOI: } 10.2174 / 1874220301603010130 & \text { Open } \\ \text { Medicine } \\ \text { lournal }\end{array}$

RESEARCH ARTICLE

\title{
Antiviral Treatment to Prevent Transmission of Hepatitis C in People Who Inject Drugs
}

\author{
Eric Dieperink* and Astrid Knott
}

Minneapolis Veterans Health Care System, University of Minnesota, Medical School, Department of Psychiatry, Minnneapolis, Minnesota, USA

\begin{abstract}
The hepatitis C virus (HCV) is common among people who inject drugs (PWID) and causes significant morbidity and mortality. Opiate replacement therapy and needle exchange programs have effectively prevented the transmission of the Human immunodeficiency virus (HIV) but have been less effective for HCV. Other HCV prevention strategies are needed. Antiviral therapy with all oral direct acting antivirals is currently available and appears to be highly effective even in PWID and offers a possible strategy to further prevention efforts. This paper will review current evidence for treatment as prevention for HCV in PWID.
\end{abstract}

Keywords: Access to care, Direct acting antivirals, Injection drug use, Liver Disease, Prevention, Substance use disorder.

\section{INTRODUCTION}

The hepatitis $\mathrm{C}$ virus (HCV) is a significant public health problem that affects over 140 million people world-wide $[1,2]$. HCV is a blood-borne illness and in high income countries the main route of HCV transmission is through injection drug use. The prevalence of HCV antibodies in PWID is approximately $60 \%$ [3]. Chronic HCV is associated with significant morbidity including cirrhosis, decompensated liver disease, hepatocellular carcinoma (HCC) and increased mortality [4, 5]. In fact, HCC is one of the few cancers that is increasing in frequency in the United States [6]. In addition, $\mathrm{HCV}$ is a leading reason for the need for liver transplantation in the United States. Eradication of HCV has been difficult as no vaccine has yet been developed and until recently antiviral treatment rates were low and treatment was effective in only $50-70 \%$ of patients. Furthermore, PWID have been typically excluded from antiviral therapy due to stigma and concerns about medication adherence and reinfection (barriers to antiviral therapy are addressed elsewhere in this supplement). However, as treatment success is expected to surpass $90 \%$ with the advent of new and direct acting antivirals (DAA's), antiviral treatment may serve as an avenue for limiting the spread of HCV and reducing its prevalence. This article will review the available data regarding "antiviral treatment as prevention" for $\mathrm{HCV}$ in people who inject drugs (PWID).

\section{Epidemiology of HCV in PWID}

Injection drug use is responsible for over $50 \%$ of current HCV infections in the United States [7]. HCV infection occurs rapidly after initiation of drug use behaviors. In one study, the median time from first injection to seroconversion was 3.3 years with greatest risk in the first year [8]. High prevalence rates (64-94\%) are found in PWID for 6 years or more [2]. Although needles likely account for most of the HCV infections, data indicate that preparation practices such as "backloading," sharing cotton, cookers and rinse water are also associated with transmission of the virus [9]. Most people who are currently infected were born between 1945 and 1965 . However, recent data indicate that there is an emerging epidemic of $\mathrm{HCV}$ among young injection drug users. Young injection drug users show prevalence rates of

\footnotetext{
* Address correspondence to this author at the University of Minnesota-Medical School, Department of Psychiatry, Minneapolis VAHC One Veterans Drive, Minneapolis, MN 55417, Minnesota, USA; Tel: 612-467-4675; E-mail: Eric.Dieperink@va.gov
} 
$20-46 \%$ with use of 5 years or less. Many started using alcohol or cannabis before age 13, began opioid use with oral oxycodone and then transitioned to heroin in 1-1.5 years [10 - 14]. One concern about this new epidemiological landscape is that these young people typically do not seek medical care or help for their drug use. Although HCV in PWID is primarily a problem in high income countries, HCV is also emerging in low and middle income countries [3, 15]. Efforts to curb HCV infection will need to account for high rates of HCV in PWID.

Although efforts to curb transmission have been instituted, including harm reduction approaches such as needle exchange programs and opioid substitution treatment, these programs have not been as successful as they have been in HIV prevention. This may be due to higher prevalence rates and easier transmission per injection for HCV [16, 17] compared to HIV $[18,19]$. A meta-analysis of studies evaluating prevention strategies for HCV infection in PWID found that no single intervention was associated with HCV seroconversion reductions. However, the analysis did show that multicomponent interventions were effective at reducing the incidence of HCV seroconversion by about $75 \%$ in PWID [20]. These multimodal interventions typically consisted of opioid replacement therapy (ORT), needle exchange programs and education. However, given the high HCV prevalence among PWID, it is estimated that these types of programs would need to cover over $80 \%$ of the population in order to reduce prevalence to $20 \%$ in 20 years [21]. $\mathrm{HCV}$ transmission in PWID is still occurring and other prevention approaches are needed, including antiviral treatment as prevention.

\section{Antiviral Treatment in PWID}

Multiple studies have shown interferon based treatment regimens can be safely administered to PWID with comparable SVR rates to those without injection drug use [22 - 24]. These studies also report that PWID show good adherence to antiviral therapy of approximately $82 \%$. Although concern for re-infection has always been a factor in restricting access to antiviral therapy in PWID, studies show low rates of re-infection after successful treatment [25, 26]. No studies using interferon free regimens have been performed but given the better tolerability, shorter duration of treatment and significantly improved response rates, it is expected that PWID will respond well.

Although interferon-based treatment is as effective in PWID as for those who do not inject, treatment rates in PWID have been low. In the U.S., Canada and Australia data indicate that approximately 15-20 per $1000 \mathrm{HCV}$ infected (1.5-2.0\%) receives antiviral therapy each year in PWID [27]. At the same time studies show that at least 70-80\% of PWID's are willing and desire to receive antiviral therapy and desire for treatment is expected to rise with DAA's [28].

Efficacy of interferon-based treatment in PWID has been dependent on integrated or collaborative approaches to care. This has typically involved teams of clinicians including hepatologists, primary care clinicians, and mental health and addiction providers that work together to address the complex needs of this population [29]. Addiction treatment settings including those offering ORT have been successful at helping patients manage and complete interferon based treatments [26, 30, 31]. In order for treatment as prevention to be successful it is likely that expansion of these integrated care approaches will be needed.

Treatment in the Human immunodeficiency (HIV) population has demonstrated that treatment as prevention can be beneficial and effective. Initially data from observational studies suggested that antiretroviral treatment (ART) reduced transmission among couples in which one partner was infected with HIV and the other was not. Randomized controlled trials subsequently confirmed the reduced risk of transmission of HIV between couples who were discordant for HIV [32] as well as in maternal-to-child transmission [33]. Data also suggest that reducing viral load in a community can reduce new HIV infections [34]. These data show that treatment not only can help an individual but may also have an impact on the population at large by limiting transmission and reducing the overall burden of disease. While HIV treatment is chronic and focused on viral suppression, HCV treatment has the potential to be curative. This makes treatment as a method of prevention in $\mathrm{HCV}$ attractive as significant reductions in prevalence and transmission can potentially be achieved.

\section{Mathematical Modeling of Treatment as Prevention}

Several studies have investigated HCV treatment as prevention in PWID using mathematical models (Table 1). Early models of interferon based treatment using an HCV prevalence of $45 \%$, an annual treatment rate of $10 \%$ and a success rate of antiviral treatment of $50 \%$ showed that a $32 \%$ reduction in HCV prevalence over 10 years was possible [35]. Another study from the United Kingdom using more realistic HCV treatment rates of 2\%, 4\% and 6\% in PWID, an $\mathrm{HCV}$ prevalence of $40 \%$ and treatment efficacy of $63 \%$ showed that $\mathrm{HCV}$ prevalence could be reduced by $15 \%, 33 \%$ and 50\% respectively over 20 years [36]. Another study showed that with an HCV prevalence of 20\%, treatment 
efficacy of $62.5 \%$ and treatment uptake of 5, 10, 20, 30 or 40 per 1000 PWID reduced HCV prevalence by 15, 31, 62 and $72 \%$ over 10 years [37]. In this study reducing antiviral treatment efficacy by $25 \%$ (i.e. to $45 \%$ ) had little effect on reductions in HCV prevalence. However, as prevalence rates rise (i.e. $20 \%, 40 \%$ or $60 \% \mathrm{HCV}$ prevalence) and if the treatment rate remains fixed at 10 per 1000 PWID, the ability of antiviral therapy to reduce HCV prevalence falls from $31 \%$ to $13 \%$ and $7 \%$ for each prevalence level, over 10 years [37]. Several other studies show similar effects of HCV antiviral treatment of PWID [38 - 42]. The data suggest that for a fixed treatment rate, the impact of antiviral therapy is greater at lower HCV population prevalence because a greater proportion of the HCV population is treated and thus the risk of re-infection is lower.

Table 1. Selected Studies of "Treatment as Prevention" in PWID.

\begin{tabular}{|c|c|c|c|c|}
\hline Author & $\begin{array}{c}\text { Year } \\
\text { published }\end{array}$ & Assumptions & Modeled Annual Treatment Rates & Relative prevalence reductions \\
\hline Zeiler et al. & 2010 & $\begin{array}{c}\text { Number of users starting } \\
\text { injecting: } 4500 / \mathrm{yr} \\
\text { SVR rate: } 50 \% \\
\text { Tx rate: } 1 \% \text { per year } \\
\text { Number of individuals starting } \\
\text { Tx: } 539.362 / \mathrm{yr} \\
\end{array}$ & $\begin{array}{c}\text { Increased tx rate to } 60 \% \text { of population of } \\
\text { PWID }\end{array}$ & $\begin{array}{c}\text { Reduces chronic infections by } 1 / 2 \text { in } 3.3 \mathrm{yrs} \\
\text { and acute infections in } 1 / 2 \text { in } 11.1 \mathrm{yrs} \text {. }\end{array}$ \\
\hline \multirow[t]{4}{*}{ Martin et al. } & \multirow[t]{4}{*}{2011} & \multirow{4}{*}{$\begin{array}{c}\text { Baseline HCV Prevalence: } 20 \% \\
\text { SVR rate (interferon based): } \\
62.5 \%\end{array}$} & 5/1000 PWID & $15 \%$ over 10 yrs \\
\hline & & & 10/1000 PWID & $30 \%$ over 10 yrs \\
\hline & & & 20/1000 PWID & $62 \%$ over 10 yrs \\
\hline & & & 40/1000 PWID & $72 \%$ over 10 yrs \\
\hline \multirow{3}{*}{$\begin{array}{l}\text { Hellard et } \\
\text { al. }\end{array}$} & \multirow[t]{3}{*}{2012} & \multirow{3}{*}{$\begin{array}{c}\text { Victoria, Australia } \\
\text { PWID population: } 25,000 \\
\text { HCV positive: } 50 \% \\
\text { Ave duration of infection: } 14 \text { yrs } \\
\text { Current Tx rate: } 1 / 1000 \text { PWID }\end{array}$} & 13/1000 PWID & $20 \%$ over 30 yrs \\
\hline & & & 17/1000 PWID & $30 \%$ over 30 yrs \\
\hline & & & 25/1000PWID & $50 \%$ over 30 yrs \\
\hline \multirow[t]{12}{*}{ Martin et al. } & \multirow[t]{12}{*}{2013} & \multirow{4}{*}{$\begin{array}{c}\text { SVR with DAA's: } 90 \% \\
\text { HCV prevalence: } \\
\text { Edinburgh, UK: } 25 \% \\
\text { Baseline Tx rate: } 8 / 1000 \\
\text { PWID }\end{array}$} & 10/1000 PWID & $32 \%$ over 15 yrs \\
\hline & & & 20/1000 PWID & $69 \%$ over 15 yrs \\
\hline & & & 40/1000 PWID & $90 \%$ over 15 yrs \\
\hline & & & 80/1000 PWID & $91 \%$ over 15 yrs \\
\hline & & \multirow{4}{*}{$\begin{array}{c}\text { Melbourne, Australia:50\% } \\
\text { Baseline Tx rate: } 3 / 1000 \\
\text { PWID }\end{array}$} & 10/1000 PWID & $9 \%$ over 15 yrs \\
\hline & & & 20/1000 PWID & $23 \%$ over 15 yrs \\
\hline & & & 40/1000 PWID & $50 \%$ over 15 yrs \\
\hline & & & 80/1000 PWID & $90 \%$ over 15 yrs \\
\hline & & \multirow{4}{*}{$\begin{array}{c}\text { Vancouver, Canada: } 65 \% \\
\text { Baseline Tx rate: } 2 / 1000 \\
\text { PWID }\end{array}$} & 10/1000 PWID & $5 \%$ over 15 yrs \\
\hline & & & 20/1000 PWID & $9 \%$ over 15 yrs \\
\hline & & & 40/1000 PWID & $20 \%$ over 15 yrs \\
\hline & & & 80/1000 PWID & $53 \%$ over 15 yrs \\
\hline Innes et al. & 2014 & $\begin{array}{c}\text { Scotland } \\
\text { PWID population: } 15,300 \\
\text { HCV positive: } 50 \% \\
\text { PWID Number treated per year: } \\
120 \\
\text { Total persons treated: } 1000 / \mathrm{yr}\end{array}$ & $\begin{array}{l}\text { Double treatment rate to } 2000 / y r \\
\text { Increase Tx of PWID by } 20 \%\end{array}$ & $\begin{array}{l}\text { Decrease HCV infections by } 52.2 \% \text { over } \\
15 \text { yrs }\end{array}$ \\
\hline
\end{tabular}

Direct acting antiviral (DAA) treatment of chronic HCV is now a reality with studies showing high treatment success rates with all genotypes. Recent studies show SVR rates with DAA's exceeds 90\% for all genotypes [43 - 46]. Antiviral therapy with DAA's is interferon free, all oral and of relatively short duration (i.e. 12 weeks). Mathematical modeling of HCV transmission and the impact of antiviral treatment with DAA's, in three settings with different HCV prevalence (Edinburgh, Scotland, 25\%; Melbourne, Australia, 50\% and Vancouver, Canada, 65\%), shows that HCV prevalence could be halved within 15 years if 15, 38 and 75 per 1000 PWID received antiviral treatment. Alternatively, increasing treatment to 40 per 1000 PWID per year could reduce prevalence by $91 \%$ in Edinburgh, 54\% in Melbourne and $22 \%$ in Vancouver [42].

Hellard and colleagues examined the impact of social networks on HCV transmission and modeled a "treat your 
friend's" approach using DAA's in PWID. Models of antiviral treatment as prevention typically assume that injectors have equal contact with other injectors. Using data regarding HCV transmission from PWID followed for 5 years the authors were able to model the "treat your friend's" approach wherein an individual is chosen at random for treatment and all their "infected neighbors" are treated as well. When compared to treatment of randomly selected nodes that does not account for knowledge of the injecting network, the authors found that the "treat your friend's" approach led to greater reductions in HCV prevalence. The authors found that treating 25 per 1000 PWID over 10 years reduced HCV prevalence from $50 \%$ to $40 \%$ for a random approach and to $33 \%$ for a treat your friends approach, further reductions were noted as more PWID were treated and as treatment efficacy was increased [39].

Another study compared antiviral treatment strategies by prioritizing treatment of either PWID or people with moderate to advanced fibrosis. Not surprisingly, prioritizing treatment of people with more advanced liver disease reduced new cases of severe liver disease but had a minimal impact on incident HCV. By prioritizing treatment of PWID, fewer new infections occurred but this strategy had a suboptimal impact on new severe liver disease cases [47]. The data suggest that policy makers in resource constrained settings will need to consider the impact and value of prioritizing the treatment of different populations on health in HCV patients.

In summary, mathematical modeling of the impact of antiviral treatment of PWID with DAA's suggest that significant reductions in $\mathrm{HCV}$ prevalence are possible. Effective treatment as prevention is dependent on $\mathrm{HCV}$ prevalence, treatment efficacy and treatment uptake. Currently, a significant barrier to reducing HCV prevalence through antiviral treatment is access and treatment uptake among PWID.

\section{Access to Hepatitis Care for PWID}

In the U.S. it is estimated that approximately 3.5 million people are infected with HCV but only $50 \%$ are aware of their infection. Of those people aware of their infection, approximately $85 \%$ have health insurance and thus are able to access care. Furthermore, many people who are aware of their HCV status do not seek care and current estimates indicate that less than $20 \%$ of the total HCV population have received antiviral therapy and only $9 \%$ have achieved a sustained virologic response (SVR) [48]. In PWID access to care and treatment rates are even lower although when PWID are treated rates of SVR are similar to other populations. Barriers to antiviral treatment exist at the patient, provider and system levels and may include lack of knowledge and awareness, financial difficulties and worries over medication side effects for patients $[49,50]$. Clinicians may have concerns about medication adherence, the risk of reinfection and may lack the knowledge or resources to address alcohol and injection drug use [51]. In addition, stigma may reduce care seeking [52].

Many people are unaware of their HCV infection and efforts to increase HCV testing and linkage to care in the injecting population are needed. Substance use treatment settings are an ideal place to provide education and testing of people most at risk for HCV. One study implemented systematic hepatitis education, HCV testing and a facilitated referral to a hepatitis clinic and the authors found that new HCV patients were identified and patients' understanding of hepatitis improved [53]. Once identified, improved access to care and treatment uptake are also needed. Antiviral treatment that takes place in the context of multidisciplinary care with hepatologists, mental health and addiction providers has been shown to be effective during the interferon therapy era [29]. Multiple observational studies suggest that integrated or collaborative care approaches to addressing HCV patients with psychiatric and substance use disorders including PWID are effective, both increasing antiviral treatment rates and improving SVR [22, 54]. A recent randomized trial of integrated care showed that HCV patients with psychiatric and substance use disorders were more likely to receive treatment and were more adherent to antiviral therapy in the intervention group than those receiving treatment as usual [55]. Integrated or collaborative care approaches are still warranted in the DAA era as patients with $\mathrm{HCV}$ and injection drug use remain a complicated group that may require and benefit from enhanced support in order to start and adhere to antiviral therapy [56]. Finally, efforts to improve testing and antiviral treatment will be necessary for treatment as prevention to be maximally effective.

\section{CONCLUSION}

Antiviral treatment for HCV has improved significantly over the past several years and offers hope that treatment of hard to reach populations such as PWID may soon become a reality. Studies show that multi-model prevention strategies can significantly reduce HCV prevalence, including needle exchange and ORT. However, in order to potentially eradicate $\mathrm{HCV}$, other prevention strategies are needed. Data from mathematical models suggest that HCV "treatment as prevention" may be one avenue that could further reduce HCV prevalence. Highly effective antiviral 
treatment with DAA's may not only help individuals with HCV but may reduce the population burden as well. In order for eradication of HCV to become a possibility, increased testing and linkage to care will be a priority. Unique approaches to providing antiviral therapy may be required, including providing antiviral therapy in substance use disorder treatment settings. Furthermore, methods for engaging and maintaining patients in care, such as integrated or collaborative models of care should continue and may need to be expanded.

\section{CONFLICT OF INTEREST}

The authors confirm that this article content has no conflict of interest.

\section{ACKNOWLEDGEMENTS}

Declared none.

\section{REFERENCES}

[1] Mohd Hanafiah K, Groeger J, Flaxman AD, Wiersma ST. Global epidemiology of hepatitis C virus infection: new estimates of age-specific antibody to HCV seroprevalence. Hepatology 2013; 57(4): 1333-42. [http://dx.doi.org/10.1002/hep.26141] [PMID: 23172780]

[2] Shepard CW, Finelli L, Alter MJ. Global epidemiology of hepatitis C virus infection. Lancet Infect Dis 2005; 5(9): 558-67. [http://dx.doi.org/10.1016/S1473-3099(05)70216-4] [PMID: 16122679]

[3] Nelson PK, Mathers BM, Cowie B, et al. Global epidemiology of hepatitis B and hepatitis C in people who inject drugs: results of systematic reviews. Lancet 2011; 378(9791): 571-83. [http://dx.doi.org/10.1016/S0140-6736(11)61097-0] [PMID: 21802134]

[4] Dieperink E, Pocha C, Thuras P, Knott A, Colton S, Ho SB. All-cause mortality and liver-related outcomes following successful antiviral treatment for chronic hepatitis C. Dig Dis Sci 2014; 59(4): 872-80. [http://dx.doi.org/10.1007/s10620-014-3050-5] [PMID: 24532254]

[5] van der Meer AJ, Veldt BJ, Feld JJ, et al. Association between sustained virological response and all-cause mortality among patients with chronic hepatitis C and advanced hepatic fibrosis. JAMA 2012; 308(24): 2584-93. [http://dx.doi.org/10.1001/jama.2012.144878] [PMID: 23268517]

[6] El-Serag HB. Epidemiology of viral hepatitis and hepatocellular carcinoma. Gastroenterology 2012; 142(6): 1264-73 e1. Epub 2012/04/28 [http://dx.doi.org/10.1053/j.gastro.2011.12.061]

[7] Klevens RM, Hu DJ, Jiles R, Holmberg SD. Evolving epidemiology of hepatitis C virus in the United States. Clin Infect Dis 2012; 55(Suppl. 1): S3-9. [http://dx.doi.org/10.1093/cid/cis393] [PMID: 22715211]

[8] Roy E, Boudreau JF, Boivin JF. Hepatitis C virus incidence among young street-involved IDUs in relation to injection experience. Drug Alcohol Depend 2009; 102(1-3): 158-61.

[http://dx.doi.org/10.1016/j.drugalcdep.2009.01.006] [PMID: 19251382]

[9] Doerrbecker J, Behrendt P, Mateu-Gelabert P, et al. Transmission of hepatitis C virus among people who inject drugs: viral stability and association with drug preparation equipment. J Infect Dis 2013; 207(2): 281-7. [http://dx.doi.org/10.1093/infdis/jis677] [PMID: 23129759]

[10] Use of enhanced surveillance for hepatitis C virus infection to detect a cluster among young injection-drug users--new York, November 2004April 2007. MMWR Morb Mortal Wkly Rep 2008; 57(19): 517-21. [PMID: 18480744]

[11] Notes from the field: risk factors for hepatitis C virus infections among young adults--Massachusetts, 2010. MMWR Morb Mortal Wkly Rep 2011; 60(42): 1457-8.

[PMID: 22031220]

[12] Hepatitis C virus infection among adolescents and young adults: Massachusetts, 2002-2009. MMWR Morb Mortal Wkly Rep 2011; 60(17): 537-41.

[PMID: 21544042]

[13] Notes from the field : hepatitis C virus infections among young adults--rural Wisconsin, 2010. MMWR Morb Mortal Wkly Rep 2012; 61(19): 358.

[PMID: 22592276]

[14] Christian WJ, Hopenhayn C, Christian A, McIntosh D, Koch A. Viral hepatitis and injection drug use in Appalachian Kentucky: a survey of rural health department clients. Public Health Rep 2010; 125(1): 121-8. [PMID: 20402204]

[15] Hajarizadeh B, Grebely J, Dore GJ. Epidemiology and natural history of HCV infection. Nat Rev Gastroenterol Hepatol 2013; 10(9): 553-62. [http://dx.doi.org/10.1038/nrgastro.2013.107] [PMID: 23817321] 
[16] Kiyosawa K, Sodeyama T, Tanaka E, et al. Hepatitis C in hospital employees with needlestick injuries. Ann Intern Med 1991; 115(5): 367-9. [http://dx.doi.org/10.7326/0003-4819-115-5-367] [PMID: 1907441]

[17] MacDonald M, Crofts N, Kaldor J. Transmission of hepatitis C virus: rates, routes, and cofactors. Epidemiol Rev 1996; $18(2)$ : 137-48. [http://dx.doi.org/10.1093/oxfordjournals.epirev.a017921] [PMID: 9021308]

[18] Hudgens MG, Longini IM Jr, Vanichseni S, et al. Subtype-specific transmission probabilities for human immunodeficiency virus type 1 among injecting drug users in Bangkok, Thailand. Am J Epidemiol 2002; 155(2): 159-68. [http://dx.doi.org/10.1093/aje/155.2.159] [PMID: 11790680]

[19] Moloughney BW. Transmission and postexposure management of bloodborne virus infections in the health care setting: where are we now? CMAJ 2001; 165(4): 445-51. Epub 2001/09/04

[20] Hagan H, Pouget ER, Des Jarlais DC. A systematic review and meta-analysis of interventions to prevent hepatitis C virus infection in people who inject drugs. J Infect Dis 2011; 204(1): 74-83. [http://dx.doi.org/10.1093/infdis/jir196] [PMID: 21628661]

[21] Vickerman P, Martin NK, Hickman M. Understanding the trends in HIV and hepatitis C prevalence amongst injecting drug users in different settings--implications for intervention impact. Drug Alcohol Depend 2012; 123(1-3): 122-31. [http://dx.doi.org/10.1016/j.drugalcdep.2011.10.032] [PMID: 22138540]

[22] Aspinall EJ, Corson S, Doyle JS, et al. Treatment of hepatitis C virus infection among people who are actively injecting drugs: a systematic review and meta-analysis. Clin Infect Dis 2013; 57(Suppl. 2): S80-9. [http://dx.doi.org/10.1093/cid/cit306] [PMID: 23884071]

[23] Dimova RB, Zeremski M, Jacobson IM, Hagan H, Des Jarlais DC, Talal AH. Determinants of hepatitis C virus treatment completion and efficacy in drug users assessed by meta-analysis. Clin Infect Dis 2013; 56(6): 806-16. [http://dx.doi.org/10.1093/cid/cis1007] [PMID: 23223596]

[24] Hellard M, Sacks-Davis R, Gold J. Hepatitis C treatment for injection drug users: a review of the available evidence. Clin Infect Dis 2009; 49(4): 561-73 [http://dx.doi.org/10.1086/600304] [PMID: 19589081]

[25] Dalgard O, Bjøro K, Hellum K, et al. Treatment of chronic hepatitis C in injecting drug users: 5 years' follow-up. Eur Addict Res 2002; 8(1): 45-9. [http://dx.doi.org/10.1159/000049487] [PMID: 11818693]

[26] Grebely J, Knight E, Ngai T, et al. Reinfection with hepatitis C virus following sustained virological response in injection drug users. J Gastroenterol Hepatol 2010; 25(7): 1281-4. [http://dx.doi.org/10.1111/j.1440-1746.2010.06238.x] [PMID: 20594256]

[27] Iversen J, Grebely J, Topp L, Wand H, Dore G, Maher L. Uptake of hepatitis C treatment among people who inject drugs attending Needle and Syringe Programs in Australia, 1999-2011. J Viral Hepat 2014; 21(3): 198-207. [http://dx.doi.org/10.1111/jvh.12129] [PMID: 24438681]

[28] Doab A, Treloar C, Dore GJ. Knowledge and attitudes about treatment for hepatitis C virus infection and barriers to treatment among current injection drug users in Australia. Clin Infect Dis 2005; 40(Suppl. 5): S313-20. [http://dx.doi.org/10.1086/427446] [PMID: 15768340]

[29] Knott A, Dieperink E, Willenbring ML, et al. Integrated psychiatric/medical care in a chronic hepatitis C clinic: effect on antiviral treatment evaluation and outcomes. Am J Gastroenterol 2006; 101(10): 2254-62. [http://dx.doi.org/10.1111/j.1572-0241.2006.00731.x] [PMID: 17032190]

[30] Backmund M, Meyer K, Edlin BR. Infrequent reinfection after successful treatment for hepatitis C virus infection in injection drug users. Clin Infect Dis 2004; 39(10): 1540-3. [http://dx.doi.org/10.1086/425361] [PMID: 15546094]

[31] Lindenburg CE, Lambers FA, Urbanus AT, et al. Hepatitis C testing and treatment among active drug users in Amsterdam: results from the DUTCH-C project. Eur J Gastroenterol Hepatol 2011; 23(1): 23-31. [http://dx.doi.org/10.1097/MEG.0b013e328340c451] [PMID: 21042221]

[32] Cohen MS, Chen YQ, McCauley M, et al. Prevention of HIV-1 infection with early antiretroviral therapy. N Engl J Med 2011; 365(6): 493-505. [http://dx.doi.org/10.1056/NEJMoa1 105243] [PMID: 21767103]

[33] Abdool Karim Q, Abdool Karim SS, Frohlich JA, et al. Effectiveness and safety of tenofovir gel, an antiretroviral microbicide, for the prevention of HIV infection in women. Science 2010; 329(5996): 1168-74. [http://dx.doi.org/10.1126/science.1193748] [PMID: 20643915]

[34] Das M, Chu PL, Santos GM, et al. Decreases in community viral load are accompanied by reductions in new HIV infections in San Francisco. PLoS One 2010; 5(6): e11068. [http://dx.doi.org/10.1371/journal.pone.0011068] [PMID: 20548786]

[35] Vickerman P, Martin N, Hickman M. Can Hepatitis C virus treatment be used as a prevention strategy? Additional model projections for Australia and elsewhere. Drug Alcohol Depend 2011; 113(2-3): 83-5. [http://dx.doi.org/10.1016/j.drugalcdep.2010.08.001] [PMID: 20832198] 
[36] Martin NK, Vickerman P, Hickman M. Mathematical modelling of hepatitis C treatment for injecting drug users. J Theor Biol 2011; 274(1): 58-66. [http://dx.doi.org/10.1016/j.jtbi.2010.12.041] [PMID: 21236265]

[37] Martin NK, Vickerman P, Foster GR, Hutchinson SJ, Goldberg DJ, Hickman M. Can antiviral therapy for hepatitis C reduce the prevalence of HCV among injecting drug user populations? A modeling analysis of its prevention utility. J Hepatol 2011; 54(6): 1137-44. [http://dx.doi.org/10.1016/j.jhep.2010.08.029] [PMID: 21145810]

[38] Hellard M, Doyle JS, Sacks-Davis R, Thompson AJ, McBryde E. Eradication of hepatitis C infection: the importance of targeting people who inject drugs. Hepatology 2014; 59(2): 366-9.

[http://dx.doi.org/10.1002/hep.26623] [PMID: 23873507]

[39] Hellard M, Rolls DA, Sacks-Davis R, et al. The impact of injecting networks on hepatitis C transmission and treatment in people who inject drugs. Hepatology 2014; 60(6): 1861-70. [http://dx.doi.org/10.1002/hep.27403] [PMID: 25163856]

[40] Hellard ME, Jenkinson R, Higgs P, et al. Modelling antiviral treatment to prevent hepatitis C infection among people who inject drugs in Victoria, Australia. Med J Aust 2012; 196(10): 638-41. [http://dx.doi.org/10.5694/mja11.10981] [PMID: 22676879]

[41] Martin NK, Foster GR, Vilar J, Ryder S. HCV treatment rates and sustained viral response among people who inject drugs in seven UK sites: real world results and modelling of treatment impact. J Viral Hepat 2014. [PMID: 25288193]

[42] Martin NK, Vickerman P, Grebely J, et al. Hepatitis C virus treatment for prevention among people who inject drugs: Modeling treatment scale-up in the age of direct-acting antivirals. Hepatology 2013; 58(5): 1598-609. [http://dx.doi.org/10.1002/hep.26431] [PMID: 23553643]

[43] Sulkowski MS, Jacobson IM, Nelson DR. Daclatasvir plus sofosbuvir for HCV infection. N Engl J Med 2014; $370(16)$ : 1560-1. [http://dx.doi.org/10.1056/NEJMc1401726] [PMID: 24738674]

[44] Zeuzem S, Jacobson IM, Baykal T, et al. Retreatment of HCV with ABT-450/r-ombitasvir and dasabuvir with ribavirin. N Engl J Med 2014; 370(17): 1604-14. [http://dx.doi.org/10.1056/NEJMoa1401561] [PMID: 24720679]

[45] Kowdley KV, Lawitz E, Poordad F, et al. Phase 2b trial of interferon-free therapy for hepatitis C virus genotype 1. N Engl J Med 2014; 370(3): 222-32.

[http://dx.doi.org/10.1056/NEJMoa1306227] [PMID: 24428468]

[46] Sulkowski MS, Gardiner DF, Rodriguez-Torres M, et al. Daclatasvir plus sofosbuvir for previously treated or untreated chronic HCV infection. N Engl J Med 2014; 370(3): 211-21. [http://dx.doi.org/10.1056/NEJMoa1306218] [PMID: 24428467]

[47] Innes H, Goldberg D, Dillon J, Hutchinson SJ. Strategies for the treatment of Hepatitis C in an era of interferon-free therapies: what public health outcomes do we value most? Gut 2014. [PMID: 25378522]

[48] Yehia BR, Schranz AJ, Umscheid CA, Lo Re V III. The treatment cascade for chronic hepatitis C virus infection in the United States: a systematic review and meta-analysis. PLoS One 2014; 9(7): e101554. [http://dx.doi.org/10.1371/journal.pone.0101554] [PMID: 24988388]

[49] Grebely J, Genoway KA, Raffa JD, et al. Barriers associated with the treatment of hepatitis C virus infection among illicit drug users. Drug Alcohol Depend 2008; 93(1-2): 141-7. [http://dx.doi.org/10.1016/j.drugalcdep.2007.09.008] [PMID: 17997050]

[50] Treloar C, Hull P, Dore GJ, Grebely J. Knowledge and barriers associated with assessment and treatment for hepatitis C virus infection among people who inject drugs. Drug Alcohol Rev 2012; 31(7): 918-24. [http://dx.doi.org/10.1111/j.1465-3362.2012.00468.x] [PMID: 22612899]

[51] Zickmund SL, Brown KE, Bielefeldt K. A systematic review of provider knowledge of hepatitis C: is it enough for a complex disease? Dig Dis Sci 2007; 52(10): 2550-6. [http://dx.doi.org/10.1007/s10620-007-9753-0] [PMID: 17406823]

[52] Zickmund S, Ho EY, Masuda M, Ippolito L, LaBrecque DR. "They treated me like a leper". Stigmatization and the quality of life of patients with hepatitis C. J Gen Intern Med 2003; 18(10): 835-44. [http://dx.doi.org/10.1046/j.1525-1497.2003.20826.x] [PMID: 14521647]

[53] Hagedorn H, Dieperink E, Dingmann D, et al. Integrating hepatitis prevention services into a substance use disorder clinic. J Subst Abuse Treat 2007; 32(4): 391-8.

[http://dx.doi.org/10.1016/j.jsat.2006.10.004] [PMID: 17481462]

[54] Newman AI, Beckstead S, Beking D, et al. Treatment of chronic hepatitis C infection among current and former injection drug users within a multidisciplinary treatment model at a community health centre. Can J Gastro 2013; 27(4): 217-3. [http://dx.doi.org/10.1155/2013/515636]

[55] Ho SB, Brau N, Cheung R, et al. Integrated care increases treatment and improves outcomes of patients with chronic hepatitis C virus 
infection and psychiatric illness or substance abuse. Clin Gastroenterol Hepatol 2015; 13(11): e1-3.

[56] North CS, Hong BA, Adewuyi SA, et al. Hepatitis C treatment and SVR: the gap between clinical trials and real-world treatment aspirations. Gen Hosp Psychiatry 2013; 35(2): 122-8.

[http://dx.doi.org/10.1016/j.genhosppsych.2012.11.002] [PMID: 23219917]

(C) Dieperink and Knott; Licensee Bentham Open.

This is an open access article licensed under the terms of the Creative Commons Attribution-Non-Commercial 4.0 International Public License (CC BY-NC 4.0) (https://creativecommons.org/licenses/by-nc/4.0/legalcode), which permits unrestricted, non-commercial use, distribution and reproduction in any medium, provided the work is properly cited. 